\title{
LXVII. On determining the longitude by occultations of the fixed stars
}

\author{
Mr. Thomas Squire
}

To cite this article: Mr. Thomas Squire (1830) LXVII. On determining the longitude by occultations of the fixed stars, Philosophical Magazine Series 2, 8:48, 442-444, DOI: 10.1080/14786443008675502

To link to this article: http://dx.doi.org/10.1080/14786443008675502

里 Published online: 14 Jul 2009.

Submit your article to this journal $[\pi$

Џ Article views: 2

Q View related articles $\asymp$ 
LXVII. On determining the Longitude by Occultations of the fixed Stars. By Mr. Thomas SQuine.

To the Editors of the Philosophical Magazine and Annals.

Gentlemen,

CCULTATIONS of the fixed stars by the moon are phænomena that would seem to offer the best means for determining the longitude of places on the earth's surface of any yet known, at least as far as regards observation; as the instant of immersion or emersion can mostly be obtained to the fraction of a second. But, on the other hand, the computations which are necessary for obtaining the desired results may, under certain circumstances, require data that are not so well established as the nature of the problem demands; and therefore, though the observations may be taken with the greatest care, yet the longitudes thence obtained may not always prove so satisfactory as the known accuracy of the observations might lead us to expect, even when the process of computation is managed with the greatest circumspection.

In confirmation of the above remarks the occultation of Aldebaran, on the 15th of October 1829, may be very properly cited as an example. The weather proving favourable at the time of this phænomenon, both the immersion and emersion of the star were accurately observed at Greenwich and at Epping; and from these observations computations have been made upon two suppositions, with the view of obtaining the respective longitudes. First, by considering the effects of parallax as computed from the altitude of the star, at the same time using the moon's semidiameter without augmentation for altitude, and the orbital angle as given in the elements. Secondly, by using the parallactic depression as found from the apparent zenith distance of the moon's centre, also her visible semidiameter, and the correct orbital angle as found for the times of immersion and emersion.

Hence, according to the first rule the immersion gives the longitude of Greenwich $=0^{s}$, as it ought to do; and that of Epping $=25^{s} \cdot 37$ E., which is also very near the truth; but the emersion makes the longitude of the former place = $23^{\mathrm{s}} \cdot 34 \mathrm{E}$ ! and that of the latter $=49^{\mathrm{s}} \cdot 34 \mathrm{E}$ !

Again, by the second rule the longitude of Greenwich $=$ $0.8 \mathrm{E}$., and that of Epping $=25^{s .92} \mathrm{E}$., according to the times of immersion ; but by emersion the longitude of Green-

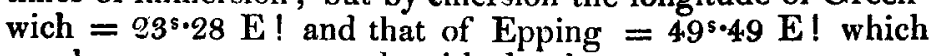
numbers agree very nearly with the above.

Here then we see that the results according to both methods are correct, or very nearly so, for immersion, yet greatly 
in excess for emersion, which might lead us to suppose that in the latter case there is some error in the observations; but as we cannot suspect this to be the case at the Röyal Observatory, and the discrepancy being nearly the same at both places, it may reasonably be inferred that the time of emersion at Epping is equally correct as that at Greenwich. And, moreovër, as both methods of computation are founded upon true mathematical principles, it were for these reasons naturally to be expected that the results for the respective places would have been the same at emersion as at immersion. But as that is not the case, some natural cause must have operated in producing an effect in the former instance that did not take place in the latter, and which, being unknown, could not enter as a compensating quantity into the elements of computation.

Before any opinion is hazarded on this point, it may be proper to observe, that in this occultation the immersion took place at the light, and the emersion at the dark border of the moon. Now it is well known that the rays of light suffer a degree of inflection when they pass near the surface of an opaque body. Hence in this case, when a direct ray of light from the star became a tangent to the dark limb of the moon, which was the absolute time of emersion, it was bent towards that body, and thence thrown off at some distance from the spectator; so that the moon had to advance a few seconds in its orbit before the star could be seen by the observer.

It is pretty evident that some phænomenon of this kind must have taken place at the emersion by which the occultation was retarded several seconds beyond what the true semidiameter of the moon, and her visible horary motion, would give. If therefore we increase the moon's radius a small quantity (in the present instance $9^{\prime \prime} \cdot 74$ ), as a compensation for the time it took for her western limb to reach the incidental point of inflection, then we shall have the longitudes of both places as correct at emersion as at immersion*.

Perhaps, after all, the above may not be considered an adequate solution of the difficulty:-if so, I can only say that I have nothing better to offer just now; and therefore hope some of your scientific readers will have the goodness to give their opinions on the subject, by pointing out the reason why correct observations of the immersion and emersion of a star at any place should not give the longitude the same, with the same method of computation founded upon a true mathematical basis. I have not thought it necessary to enter minutely into the method of solution, as that must be evident to most

* Some observations on the value of the Moon's infection will be found in No. 29 of the Proceedings of the Astronomical Society, p. 190.-EDrT. 


\section{Notice of the Arrival of some Summer Birds of Passage}

who are at all acquainted with investigations of this nature. A polar compression of $\frac{1}{300}$ has been adopted in the computations; and the logarithms, \&c. have been carried to seven places of decimals. I am, Gentlemen, yours, \&c.

Epping, Nov. 16th, 1830.

\section{Thomas SQuire.}

LXVIII. Notice of the Arrival of Troenty-six of the Summer Birds of Passage in the Neighbourhood of Carlisle, together with some of the scarcer Species that have been met with in the same Vicinity during the Year 1830; with Observations, \&c. By A Correspondent,

\begin{tabular}{|c|c|c|c|c|c|}
\hline No. & English Specific Names. & $\begin{array}{l}\text { Latin } \\
\text { Speci }\end{array}$ & obs & & No. \\
\hline $\begin{array}{r}1 \\
2 \\
3 \\
4 \\
5 \\
6 \\
7 \\
8 \\
9 \\
10 \\
11 \\
12 \\
13 \\
14 \\
15 \\
16 \\
17 \\
18 \\
19\end{array}$ & 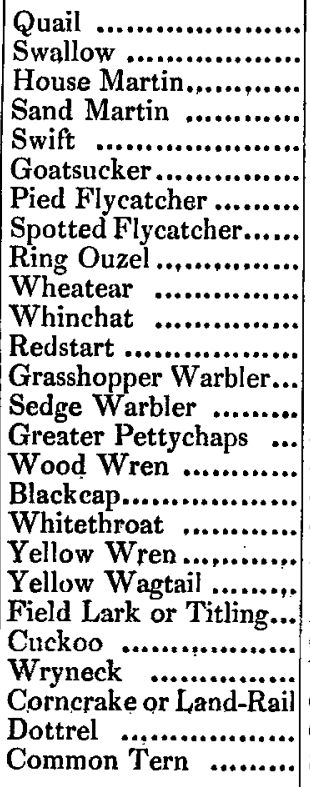 & $\begin{array}{l}\text { Coturnix vu } \\
\text { Hirundo ru } \\
\text { cyprelus Af } \\
\text { Caprimulgu } \\
\text { Muscicapa a } \\
\text { Turdus torq } \\
\text { Saxicola CE } \\
\text { Sylvia Phol } \\
\text { Curruca Lo } \\
\\
\\
\\
\end{array}$ & $\begin{array}{l}\text { May } \\
\text { April } \\
\text { March } \\
\text { April } \\
\text { May } \\
\text { April } \\
- \\
-\end{array}$ & $\begin{array}{r}7 \\
6 \\
26 \\
29 \\
28 \\
1 \\
23 \\
28 \\
22 \\
1 \\
23 \\
10 \\
8 \\
28 \\
2 \\
28 \\
10 \\
27 \\
10 \\
12 \\
18 \\
23 \\
13 \\
23 \\
12 \\
29\end{array}$ & $\begin{array}{r}6 \\
35 \\
36 \\
36 \\
37 \\
38 \\
41 \\
42 \\
49 \\
53 \\
54 \\
57 \\
58 \\
59 \\
62 \\
63 \\
64 \\
66 \\
70 \\
75 \\
78 \\
121 \\
125 \\
129 \\
164 \\
235\end{array}$ \\
\hline
\end{tabular}

Note.-The figures contained in the column on the right in the above Table, as well as those affixed to the species not included in it, refer to the numbers in Fleming's History of British Animals, which we have inserted, in order that the reader who wishes to have a description, or see the various synonyms of any of the birds here alluded to, may find the species at once, should he possess that highly useful and most excellent work. 